PLANTS PEOPLE

POSSIBILITIES

\title{
Arceuthobium Oxycedri and Its Distribution
}

\section{Author(s): W. B. Turrill}

Source: Bulletin of Miscellaneous Information (Royal Botanic Gardens, Kew), Vol. 1920, No. 8 (1920), pp. 264-268

Published by: Springer on behalf of Royal Botanic Gardens, Kew

Stable URL: http://www.jstor.org/stable/4120230

Accessed: 25-06-2016 18:12 UTC

Your use of the JSTOR archive indicates your acceptance of the Terms \& Conditions of Use, available at

http://about.jstor.org/terms

JSTOR is a not-for-profit service that helps scholars, researchers, and students discover, use, and build upon a wide range of content in a trusted digital archive. We use information technology and tools to increase productivity and facilitate new forms of scholarship. For more information about JSTOR, please contact support@jstor.org.

Royal Botanic Gardens, Kew, Springer are collaborating with JSTOR to digitize, preserve and extend access to Bulletin of Miscellaneous Information (Royal Botanic Gardens, Kew) 
champ oú fût creé Adam et est merqué d'un Terebinthe, qui a trois arbres sortant d'un tronc." This field was evidently not the same where the present Abraham's oak stands, but farther north where the Jewish tradition has for a long time located the house of Abraham in Mamre. (See Ritter, Erdkunde, XVI. iii. 225.) When this terebinth disappeared is not known; it does not seem to have been seen by the numerous travellers who visited Hebron after Belon. But it seems that following on its destruction the tradition of Abraham's house was transferred to the great Sindian oak to the west of the present Hebron.

Some kind of tree cult seems to have been attached to the great trees of Hebron since the earliest times, perhaps as a relic of real tree worship. It has been suggested (Rosenmüller, Bibl. Naturg. 232), that the old Hebrew word for them, Allon or Aelon, signified originally any big tree, just as "oak" is frequently used in the same sense. If that is so, the oak and the terebinth must always have had the monopoly of the claim to that name although we may not be able to decide which of the two was Abraham's tree.

\title{
XLII.-ARCEUTHOBIUM OXYCEDRI AND ITS DISTRIBUTION.
}

\author{
W. B. Turrill.
}

The generic name Arceuthobium, M. Bieb., Fl.Taur., 3, p. 629, 1819 , is one of the Nomina Conservanda of the Vienna Rules, being antedated by Razoumowskia, Hoffm. Hort. Mosq., 1808. This latter name is used by many authors, especially American, instead of Arceuthobium. About 18 species are known, all except four being confined to North America. The genus is allied to Viscum but is well distinguished by the anthers being distinct from the petals and not adnate to them for the whole or greater part of their length.

An interesting account of the genus entitled "Überblick über die Arten der Gattung Arceuthobium (Razoumowskia) mit besonderer Berücksichtigung ihrer Biologie und praktischen Bedeutung " by C. von Tubeuf, has recently appeared in Naturw. Zeitsch. Forst- und Landw., 1919, pp. 167-273. This paper deals more especially with the anatomical, physiological and practical questions connected with the genus and is chiefly concerned with American species. The distribution of the extra-American species is not given in detail and two of the recently described ones are not mentioned. A long bibliography is appended.

Of the four species not found in America three can be briefly referred to here. Arceuthobium minutissimum, Hook. f., is limited to Kashmir and Nepal, where is occurs on Pinus excelsa. It is one of the smallest Phanerogams known, being only 2-5 mm. in length. A. chinense, Lecomte in Not. Syst., vol. iii. p. 170 (1915), is parasitic cn Abies in the province of Yunnan. A. Dacrydii, Ridley in Journ. Fed. Malay States Mus., vol. vi. p. 170 (1915), is parasitic on Dacrydium Beccarii " near the camp on the Padang," Gunong Tahan, Pahang. 
The species with which we are now chiefly concerned is Arceuthobium Oxycedri, M.Bieb., l.c., a plant having a wide distribution in the Mediterranean Region and well known as a parasite on various junipers. The following list of localities from which it has been recorded has been made as complete as possible. An exclamation mark indicates that the writer has seen a specimen from the place named.

Spain. Old Castile, Cabreros! Near El Escorial and near S. Lucar de Barrameda (Willk. et Lange, Prod. Fl. Hisp. vol. i. p. 24).

France. Basses Alpes, Sisteron! Several localities between Sisteron and Montpezat (Rouy et Fouc., Fl. de Fr., vol. xii. p. 284). Hautes Alpes, Ribiers! Var, several localities (Alb. et Jahan, Cat. Pl. Var, p. 422). Bouches-duRhône, Mimet, Marseille (Rouy et Fouc., l.c.).

Istria. Distr. Capodistria, between Brezzi and Puzzole! Carcauzze! Near Corte d'Isola, on the eastern slopes of the Vanderinga Valley and near Borutto (Pospichal, Fl. des Oesterr. Küstenl., vol. i. p. 421).

Croatia. Zengg (Beck, Illyr. Länder, Engl. u. Drude, Veg. der Erde, vol. iv. p. 73).

Dalmatia. Near Fiume! Between Buccariza and Porto-Ree!

Epirus. Near Syraku, at the foot of Mt. Peristeri (Halácsy, Conspec. Fl. Graec. vol. i. p. 696).

Albania. Distr. Hoti, Bukovik! Distr. Janina, between Paleochori and Syrareon! Mt. Tomor!

Greece. Mt. Oeta! Mt. Parnassus! Thessaly, near Chaliki, Krania, Klinovo, Sermeniko in Pindus (Halácsy l.c.).

Macedonia. South Macedonia, without precise locality! Xerolivadon (Vandas, Reliq. Formanek., p. 251).

Serbia. Kopaonik, Stol, and Cačaker (Beck, l.c. p. .93).

Bulgaria. Above Stanimaka (Velenovsky, Fl. Bulg. Suppl. i. p. 140).

Azores. Mt. Pico!

Algeria. Prov. Oran, Vaida! Near Batna! Gharrouban! Dhaya! Lella-Khadidja, Teniet, Aures, etc. (Batt. et Trab. Fl. de l'Alg., p. 786).

Asia Minor. Amasia, Ak Dagh! Taurus, Cilician Gates! Sivas. Syria. Lebanon, Amanus and Akher Dagh (Post, Flora of Syria, Palestine and Sinai, p. 712).

Armenia. Riltzagadsch! Alliper Dagh !

Kurdistan. Oroomah!

Caucasus. Tiflis!

Crimea. Sudak, Mt. Pertsch!

N.E. Persia. Near Radkan (Boiss. Fl. Or. vol. iv. p. 1068)

Punjab-Himalaya. Lahul!

Tropical Africa. Aberdare Mountains!

The plant has also been said to occur in Portugal and Corsica, but no specimens have been seen from these countries by the writer, nor have trustworthy records been traced. The Arceuthobium Oxycedri of Hooker, Fl. Bor. Amer., vol. i. p. 278, tab. 
xcix., appears to be chiefly A. campylopodum, Engelm., though the plate also contains figures of the European A. Oxycedri, M. Bieb. A good figure with dissections of the European A. Oxycedri is to be found in Reichb., Ic. Fl. Germ., vol. xxiv. tab. 141.

The Tropical African locality given above is of exceptional interest since the plant has not previously been known to occur outside the Azores, the Mediternanean Region, and Western Asia. The specimen was collected by Mr. W. J. Dowson on the northwestern slopes of the Aberdare Mountains in British East Africa, at $6500 \mathrm{ft}$. altitude, growing parasitically on Juniperus procera, Hochst. This juniper has been fully dealt with in the Flora of Tropical Africa, vol. vi. Sect. 2, p. 336. It is the only species of the genus occurring in Tropical Africa and is widely distributed in Eritrea, Abyssinia, Somaliland, Uganda, British East Africa and Nyasaland. The tree is a most valuable timber tree in East Africa, as indicated by Hutchins, Rep. Forests on Kenia in Col. Rep. Misc. No. 41 (1907), p. 15. Since Arceuthobium is a parasite comparable in its effects on the host to the mistletoe and other Loranthaceous parasites its presence in East Africa may be of some economic importance.

In connection with the record of Arceuthobium on the Aberdare Mountains, a paper on "Fomes juniperinus and its occurrence in British East Africa," by Miss E. M. Wakefield in the Kew Bulletin, 1915, p. 102, may be mentioned. Fomes juniperinus is there recorded for the first time on Juniperus procera in East Africa. Its previously known distribution was United States and Russia. The geographical distribution of fungi is known often to be erratic, but the partial coincidence in distribution between the two juniper parasites Arceuthobium and Fomes juniperinus is interesting.

It is well known that Arceuthobium has explosive or sling fruits. A paper by Dr. T. MacDougal in Minnesota Botanical Studies, vol. ii. p. 169,1899 , deals in detail with the explosive mechanism of an American species. The American representatives of the genus like the Old World ones have very local and discontinuous distribution, and in this connection the methods of seed dispersal have to be carefully considered. In MacDougal's paper, quoted above, it is pointed out that the only localities which offer suitable conditions for the germination of the seeds are the tips of branches or the shoots of young trees underneath, and no animals are to be found in the habitat of the parasite which would in ordinary usage carry the seeds to these locations. Studies in Northern Arizona showed that the distribution has a direct connection with the vertical movements of the air. Rising air expands and cools, and in consequence the dew point is lowered or the relative humidity increased. This gives a condition most favourable for germination of the parasite, which is found in abundance along the margins of hills and the rims of cañons.

E. Heinricher, in Centralbl. f. Bakteriobiologie, vol. xlii. p. 705,1915 , states that the seeds of Arceuthobium will only germinate under the following conditions: presence of a living 
or organic substratum, light, and a chemical stimulus (probably that provided by cellulose). Other authors have urged the importance of moisture or even liquid water for germination.

The explosion which accompanies the destruction of the fruit will shoot the seed some 30 to $40 \mathrm{ft}$., but some other cause must account for the wide and discontinuous distribution of Arceuthobium Oxycedri. There is no evidence that the fruits are eaten by birds, but the possibility of an exploding fruit hitting a bird must be considered. The likelihood of this happening is decidedly increased by the fact that the jerk of a bird alighting on a slender branch would cause all the mature fruits near to explode and to scatter their seeds in all directions. Many species of birds are widely spread in the Mediterranean Region, and the long migrations of some species would enable them to transport seeds stuck to them for great distances. Thus, a colony of the Yellow Wagtail (Motacilla campestris), is found from South-East Russia to Turkestan in summer, and winters in South Africa. The chances seem in favour of such a bird now and again getting a sticky seed, such as one of Arceuthobium, stuck to its feathers and getting rid of it either en route or at its destination. That Arceuthobium is not more widely distributed by this means is probably due to its dependence on a narrow range of host-plants and on certain conditions for germination, but it is difficult to see how its spread to Tropical Africa can be otherwise explained. Warming, "Botany of the Faeroes," pp. 676-678, gives very strong evidence against birds acting as regular fruit and seed dispersal agents over long distances, but it is to be noted that the observations quoted were all made in the colder North Sea area, and in any case do not eliminate the possibility of occasional transport by birds from one country to another. As regards the discontinuous distribution of the genus Arceuthobium in the North Temperate Zone a classification of it with the "Tertiary Relicts" which are so conspicuous a feature in any analysis of European vegetation is suggestive. However, from what has been said above, it seems more reasonable to think of Arceuthobium Oxycedri with its distinctive method of seed-dispersal apart from the majority of such Tertiary relicts as Forsythia, Ramondia, etc., and to conclude that it owes its present discontinuous distribution, in part, at least, to causes still working rather than to changing climatic and topographic conditions having broken up a once continuous distributional area. It is, of course, extremely probable that the wide gap between the Tropical African and Mediterranean or Asiatic stations will be more or less bridged by the discovery of Arceuthobium in intermediate localities, perhaps on the junipers of Eritrea, Somaliland, Abyssinia or South Persia.

That Arceuthobium Oxycedri is not alone among Mediterranean plants found on Tropical African mountains is evident from a study of their flora. Thus, Engler, in a paper in the Annals of Botany, vol. xviii. p. 523 (1904), records the following species or genera with closely allied species which occur both in the Mediterranean Region and in Tropical Africa: Luzula, Anthoxanthum, Koeleria cristata, Arabis, Subularia, Stenophragma Thalia- 
num, Cerastium, Sanicula europaea, Sambucus, Veronica, and Populus euphratica. To these might be added Erica arborea.

Guppy, who was the first to record Arceuthobium Oxycedri from the Azores (" Plants, Seeds and Currents in the West Indies and Azores," pp. 426-427) comes to the following conclusion: " It is thus likely that birds actively disseminate the species, carrying the seeds firmly adhering to their plumage. In this respect Arceuthobium resembles Luzula . . . and it is noteworthy that the two genera have a similar distribution."

The genus Arceuthobium has not been definitely recorded in the fossil state, but Loranthacites succineus, Conw., Patzea Johniana, Conw., and P. Mengeana, Conw., described and figured by Goeppert, Menge und Conwentz, Flora des Bernsteins, pp. 135-138, tab. xiii. ff. 6-20, could well represent the ancestors or relatives of our genus, though, since the structure of the fruit is unknown, nothing can be said definitely on this subject.

The following species of Juniperus have now been recorded as host-plants of Arceuthobium Oxycedri: J. Oxycedrus, communis, rufescens, drupacea, Sabina, brevifolium (Azores) and procera (Trop. Afr.).

\section{XLIII.-THE ARBORETUM AND PINETUM AT BICTON. \\ W. J. BEAN.}

Sixty to eighty years ago no garden in the south of England was more famous than that at Bicton. It owed its fame then chiefly to the excellent cultivation carried on there of orchids, stove and greenhouse plants, pine-apples and other indoor fruits, as well as to its flower gardening in the open air. At the present time the pilgrim to Bicton is attracted thither chiefly by its collection of conifers.

But the garden proper is full of charm. Largely formal in character, it has that serene dignity which comes with age to all such gardens designed at the outset on broad, adequate lines. There are no irritating trivialities here, unless one takes exception to a row of bay trees severely trimmed to low standards, each a naked stem surmounted by a bun-shaped top of branches. The garden is situated on a slope, and the lower section is an arrangement of water at different levels, canalised and in rectangular pools, with smooth perfect lawns between, the whole diversified by ancient Irish yews and some beautiful old leaden statuary. The garden is enclosed on each side of the slope by high walls clothed with vegetation, outside which lofty trees make a perfect frame for the whole.

The Bicton of early Victorian days was the home of Lord Rolle, an ardent patron of horticulture, to whom tree-lovers of our own time are indebted for the foundation of the magnificent Pinetum about 1841 . Unhappily he died, comparatively young, in 1842, probably before the planting was completed, but the work he initiated was vigorously carried on by Lady Rolle, his 